\title{
MORPHOLOGY AND METABOLISM OF OTOCONIA OF GUINEA PIG
}

\author{
NOBUHARU TAGASHIRA, M. D.
}

Department of Otolaryngology, Hiroshima University School of Medicine, Hiroshima

(Director: Y. Harada, M. D.)

Morphology and metabolism of the otoconia were studied by scanning electron microscope and $\mathrm{x}$-ray microanalyzer.

The experimental animals (albino guinea pig) were divided into two groups. The first group served as control and the second group were treated with streptomycin sulfate (SM). In control animals, the shape of the otoconial crystal of the utricular macula was cylindrical with two pointed ends. In this group, unusual otoconia were also observed in the deep layer of the otoconial crystalline layer. Furthermore, some decrease in number of otoconia was noted in $40 \%$ of this group.

All of SM administrated animals showed marked reduction of otoconia. This indicates that SM disturbs the metabolism of the otoconia. Two months after cessation of SM injection, it was found that the otoconia on the otochnial membrane increased in number, suggesting regeneration of the otoconia.

There were small granules observed on the surface of the otoconial membrane and also on the other side of the otoconial membrane which faces the sensory epithelia. These granules contained certain amount of calcium. These findings suggest that the small granules are a precursor of the atoconia. Numerous granular substances were observed on the surface of the sensory epithelia. It was also found that these granular substances were transformed into the otolithic crystal. There were many protrusions from the surface of the supporting cells surrounding the sensory hair cells. These protrusions and granular substances contained some amount of calcium. Some specimens were also freeze-cracked and observed in the same way.

In the cracked specimens, small granules were found in some cells and these granules also contained some amount of calcium. Therefore, it is suggested that precursors of otoconia may be secreted from the supporting cells.

On the surface of the perimacular dark cells, numerous otoconia were observed. They appeared fragmented and shrunken. Their surface was irregular like a pumice stone. These deformed otoconia contained smaller amount of calicium than the normal.

The author found new mesh-like substances on the surface of the dark cells. These substances were various in shape and had many micropores. It was concluded that the calcium ions are actively absorbed by dark cells and the mesh-like substance is an organic matrix of the otoconia. 


\section{A85-1076-24010}

\section{モルモット耳石の形態と代謝}

公島大学医学部耳悬咽啒科学教室（主任：原日康大教授）

田頭宣治

\section{1 緒 言}

内耳飞存在する耳石器はいわゆる直線加速度を感受す る感覚器であり, 回忶加速度を感受する半規管ととむに 身体平衡維持に関与していることはすでよく知られて いる. しかしながら, この取石器についての発生, 形態 などについては、まだ種々の末解決な問題がありここ 数年来この小器官に対して大きな興味がもたれている。 耳石について初めて記载したのは Breschet (1836) ${ }^{1)}$ で, 魚の平衡斑に“massive stone” が, また春椎動物の平 衡斑住小さな結晶構造をむつ物質の存在することを確 認し，これを“otoconia”古るい法“"statoconia”之呼 んだ.

この後, 耳石の形態, 成分飞ついての研究怯数多くな され, 透過型電顕, X線回析, あるいは走查型電顕によ る観祭で㗘乳動物の耳石が炭酸カルシウムの結晶である ことが明らかにされた 2)-4)。さらに耳石結晶の形成にあ たっては, organic matrix と称される物質がその基本物 質となること无判ってきた ${ }^{576)}$. 一方アミノ配糖作系抗 生物咓であるストレプトマイシン，カナマイシン（以下 $\mathrm{SM}, \mathrm{KM}$ と略す）などいわゆる耳毒性物質は聴敩器, および前庭器の感觉細咆傽害を与兄ることが知られて いる7) 11). 特に SM は前庭器毛細胞により強い毒性を 持っていることが知られている. また最近では平衡班上 の耳石飞る障害を及社すことが報告されている この上万取石の変性が確認された飞もかかわらず, 耳 石の生成と代謝飞ついては未知の部分が多く, 最近の原 田の報告1617) の他には未だ定説がないようである. 本 研究は平衔斑上の耳石の正常形態と分布漛式を詳細に钼 祭するとと机，耳毒性物蜇投与した際の耳石の形態 変化，ならびそ再生過程安観察した. 併せて, 前庭暗細 胞領域, 耳石膜袈面, 平衡斑感覚上皮表面招上びその割 断面を走查型電影, X線マイクロアナライザーで観察, 分析し, 耳石の生成過程関して若干の新知見を得たの でここと報告する。

\section{II 研究方法}

实颂動物飞は体重約 $300 \mathrm{~g}$ の成熟モルモットを使用し た. control 群として涠処置のモルモット10匹を用いた。 一方硫酸ストレプトマイシン（SM）投与群は20匹を一 群とし，4群 (計 80匹) とした。これらの各群の動物は

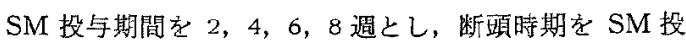
与終了後 $1 ， 2 ， 4 ， 6 ， 8$ 週の要群に分けた. すなわち, 一西群は 4 匹となり，8側耳方試料を作製した。な和 $\mathrm{SM}$ は $250 \mathrm{mg} / \mathrm{kg}$ を， 1 週每に体重補正をしながら隔 日に腹腔内人注射した。試料作製に際して, 動物はネン ブタール麻酔下断頭され，直ちに側頭骨々胞を摘出 後，骨胞を開放して $2 \%$ \%゙タールアルデハイド $(\mathrm{pH}$ 7.4 燐酸緩衝被）中で 3 時間固定した。この後卵形翌

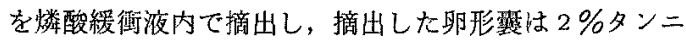
ン酸液で 1 時間，続いて $2 \%$ オスミウム酸 $(\mathrm{pH} 7.4$ 燐 酸緩衝液加)で 1 時間重固定した。 その後, 試料学上昇 エタノール系で脱水, 酷酸インアルミにて置換後, 臨界 点乾燥 $\left(\mathrm{CO}_{2}\right)$ を行い, 金スパッタコーティングを行な st.

一方，無処置群の畉形翼のうち，その一部は卵形擎班 感觉上皮層表面，およびその割断面の観察江用いた。感 覚上皮層表面竞露出させるには, 燐酸㣪衙液内で注射器 による噴流を利用して耳石膜，耳石層を剥離した。また

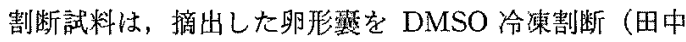
氏法）飞て割断作製し，この後の過程は前述の方法飞従 った. 推察炕 JSM F 15, JSM T-200 走查型電子 顕微鏡を使用し，カルシウム元索の分析には JEOL NEWMAX 1500 X-RAY MICROANALYZER を用 Wた.

\section{III 結 果}

1) 卵形票斑耳石膜上の耳石の形態

卵形露火和ける耳石の形態とその分布様式を明らかに するため，卵形雚斑を図1のごとく10区画に分けて観察 lた. 


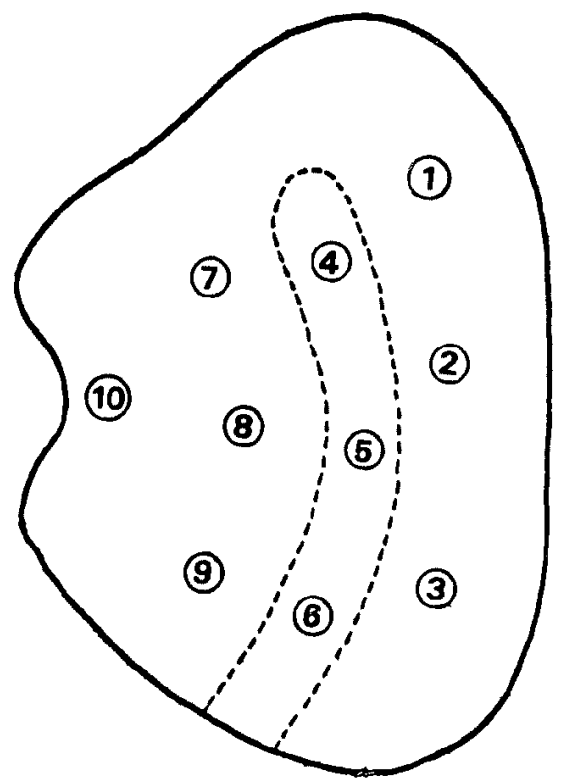

図 1

i）無処置群

畉形裂斑全体の形態は過去の報告通り，モルモットで はいわゆる貝款状で，その前方は水平面に対して上方 傾斜し，外側は下っていた（図 2). 耳石の形態とその 分布様式汇個体によって多少の相晎はあるものの，大体 同しような傾向を示していた．まず耳石層の最も外側辺 縁部（区画(1)(2)の最も端飞相当する部）では長径 1〜 $3 \mu \mathrm{m}$ の小型の耳石が大部分古占めていた。これらの耳 石は他の部でみられるような，両端に三面構造を持たず 卵型をしていた（図3）。辺緣部より内側で striola 部上 の間の表層飞は両端飞三面構造夲有する円柱状の耳石 (cylindrical type) が大部分を占めていた.このタイプ の耳石は円柱状の体部と，三面を境する稜線が軽い円孤 を描く美しい結晶形をして和り，その大ささは長佳が $4 \sim 5 \mu \mathrm{m}$ と最外側の卵型のものよりやや大型であった (図 4).このほかにも $1 \mu \mathrm{m}$ 以下の極めて小さい耳石む 観祭されたが，こういった耳石は全ての区画にみられ， し加も大型耳石に付着して物り，集団老成して存在して いるここはなかった。一方，試料作製時に生じた表層耳 石の䟝離した部分加ら下層の耳石が観祭された。一般に 下層に存在する耳石は表層の耳石とその形態がやや異な って扣, 円錐状の屯のや，夕ル状のむのむみられた （四 5，6）。また，その大きさは表層の耳石に比べて

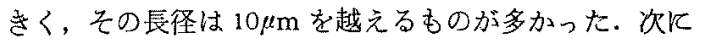

striola 部に相当する区画（図 1 の(4)(5)部）ではやや小 型で $2 \sim 3 \mu \mathrm{m}$ の長径を有する円柱型や眼型の耳石が混 在していることが多かった．また個体によっては長径 $10 \mu \mathrm{m}$ のダンベル状をしたもの，あるいは円柱型で大型 のものが比較的多くみられるすのむあった. 一般にこれ らの表層にみられた大型耳石は層状構造をなしており， 体部の中央部でくほんでいるものが多かった。このよう に striola 部では個体によって差異はあるすのの，耳石 の形態は一様性がないように思われた（図 7)。また， striola 部では，無処置動物です耳石層が極端滛いも の，あるいは殆んど耳石が然く下層の耳石膜が露出して いるものもあった（図8）。この現象は左右の耳石器

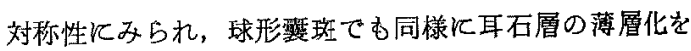
伴ない，耳石層の全体的な密度は球形慜斑のほうが眆形 琣斑よりあ少ないという傾向がみられた。このように耳 石密度の少ない平衡斑上の耳石は10 20 $\mu \mathrm{m}$ にあ区ら大 型で，層状構造を有するダンベル型のものが極めて多か った（図 9). 以上のような 無好置動物で 耳石の堿少を みたものは的40\%であった。

striola の内側（区画(7)(8)(9) では長径 3〜 $4 \mu \mathrm{m}$ の月 柱状の耳石が主体であったが,これに混ざって型のやや 崩れた細長い耳石がみられた。この型の耳石は円柱型の 耳石体部が円柱状であるのに対し，不規則な層状構造を なした平偏なもので, 耳石結晶の両端に三面構造はみら れなかった.これは striola 部で比較的多くみられたダ ンベル状の耳石と円柱型耳石との中間型に属する結晶型 と思放れた（図 10）。丞人部付近では最外側辺縁部でみ られたよらな卵型の小型耳石と, 円柱型をした小型の耳 石が混在していた，一方畉形翼斑を割断することによっ て今まで観察することが困難であった最下層の耳石を詳 細に観察する事が可能となった。この部の耳石結晶は各 々の結䐯が石垣状飞組み合って和り，あたかす龟裂が入 って割れてゆく過程にあるもののよろに思われた. しか も, これら最下層の耳石形態は表層に存在する耳石のよ うに一様性がなく，その交面構造も粗であった．また三 面構造を境する稜線は，乙の尾根に相当する部が鈍であ り，最㳭部に存在する耳石は多くの点で表層の耳石とは 異なっていた.

以上のように正常モルモットの卵形聚斑での耳石の形 態は，表層のあのでは，雨端に三面構造を有する円柱型 の結晶が主体を成して招り，その他卵型，ダンベル型， 用柱型とダンベル型の中間型といったものが少数みられ た、また，耳石層の澡部では表層の耳石よりす大型で， 
田頭 論 文 付 図 (1)
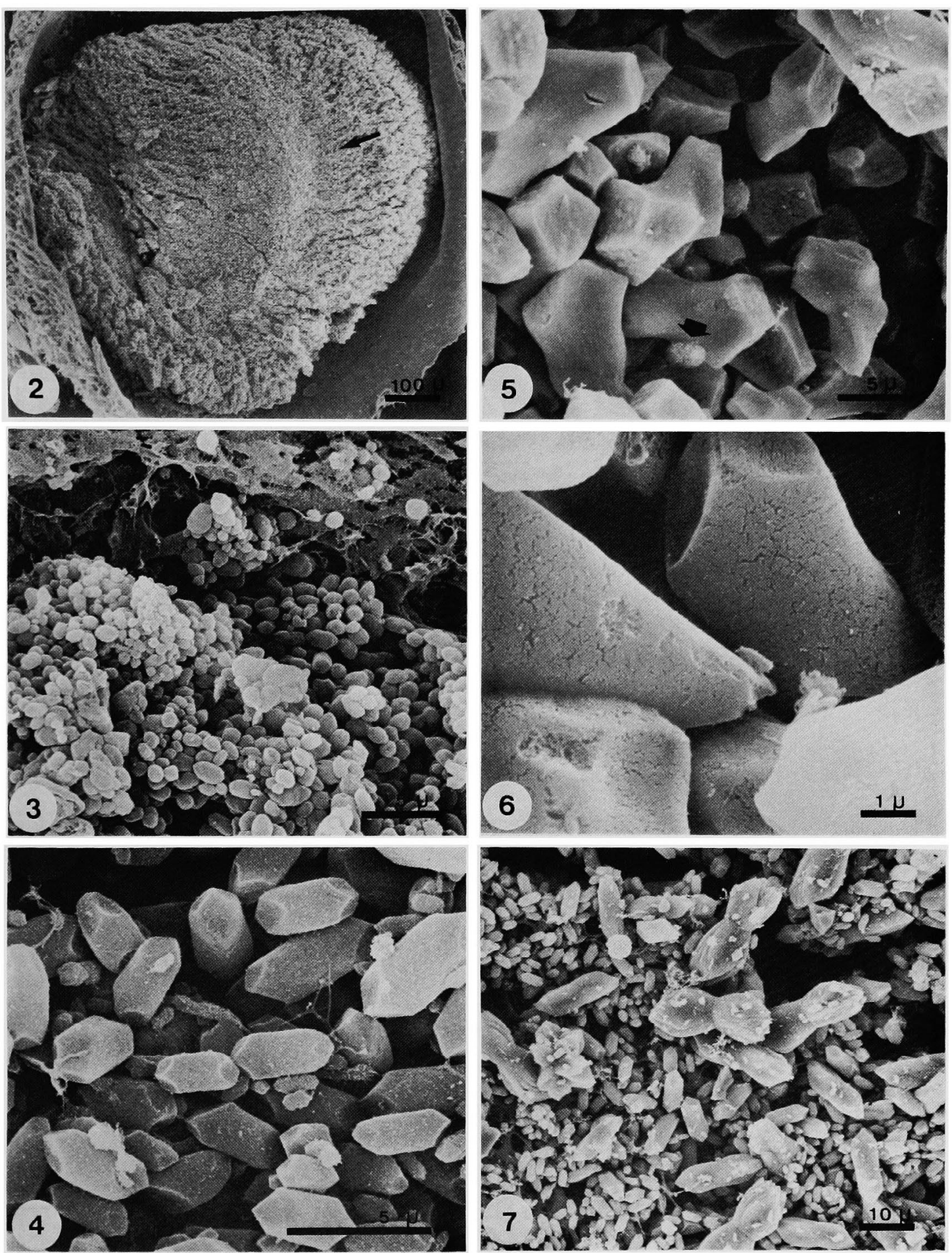
田頭 論 文 付 図 (2)

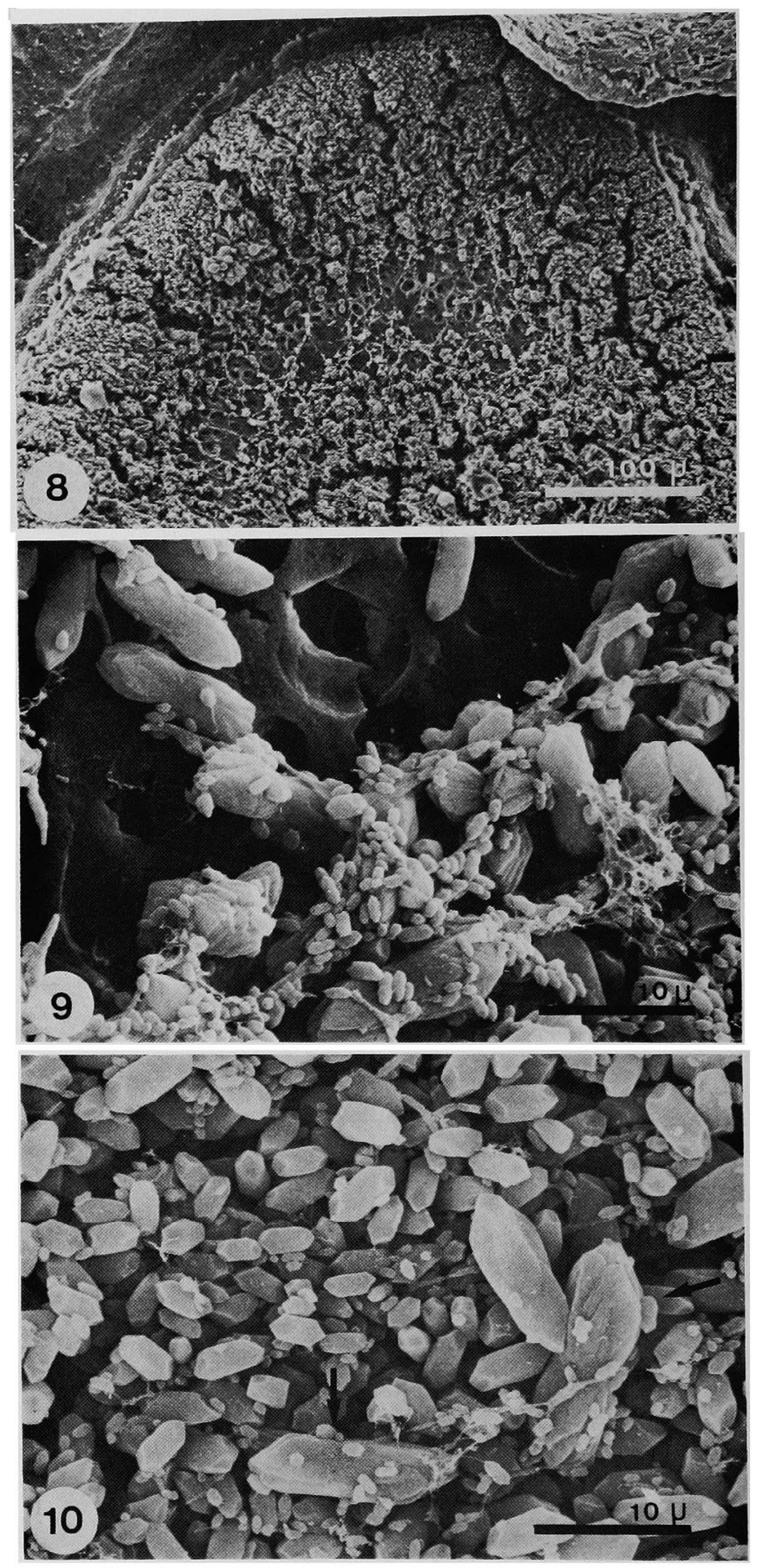


田頭論文付図 (3)
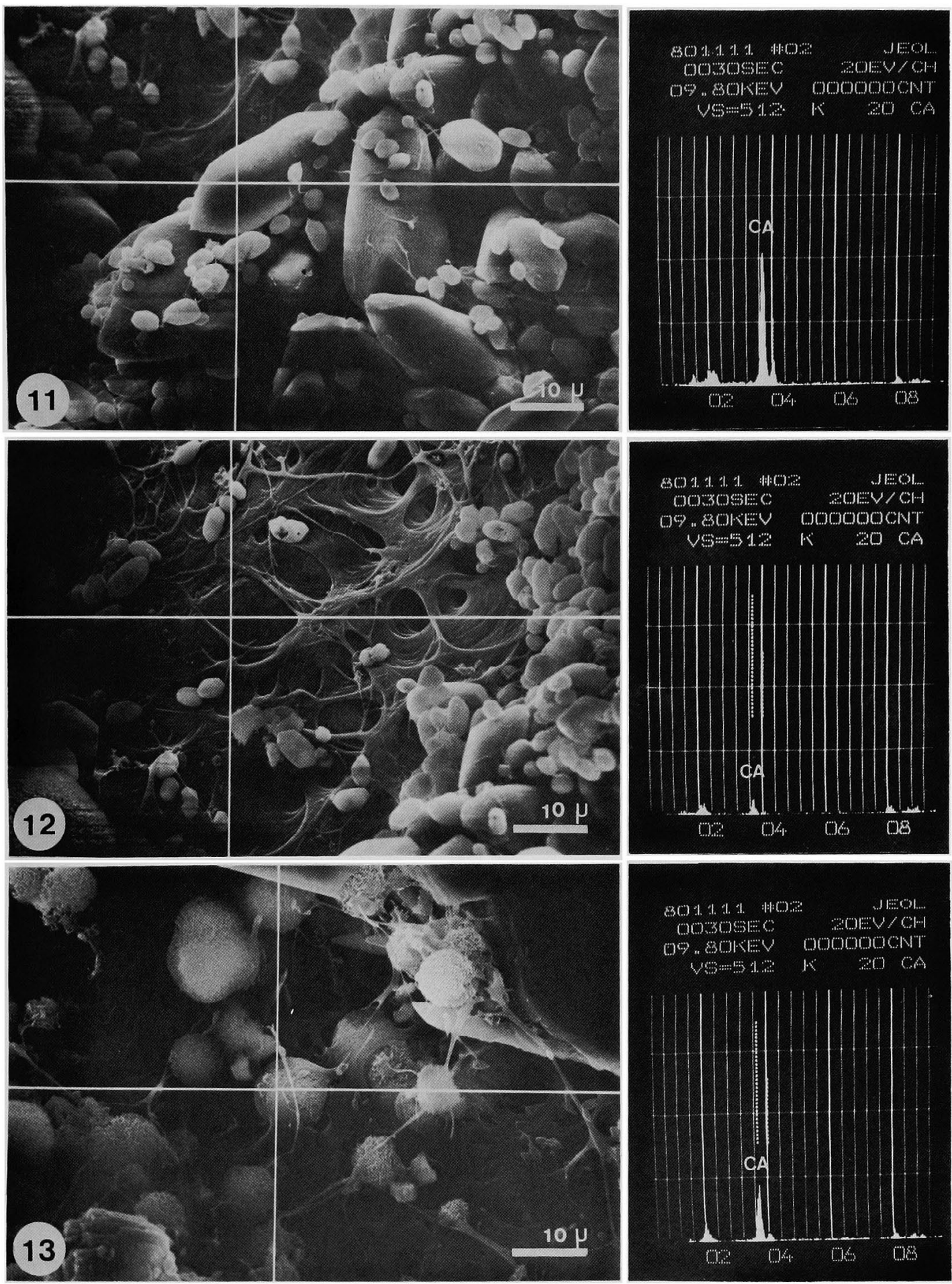

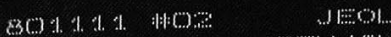

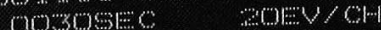

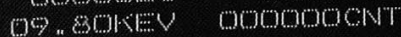

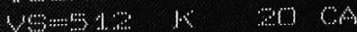

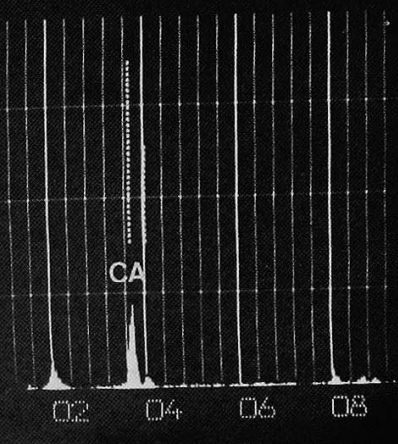


田頭論文付図 (4)
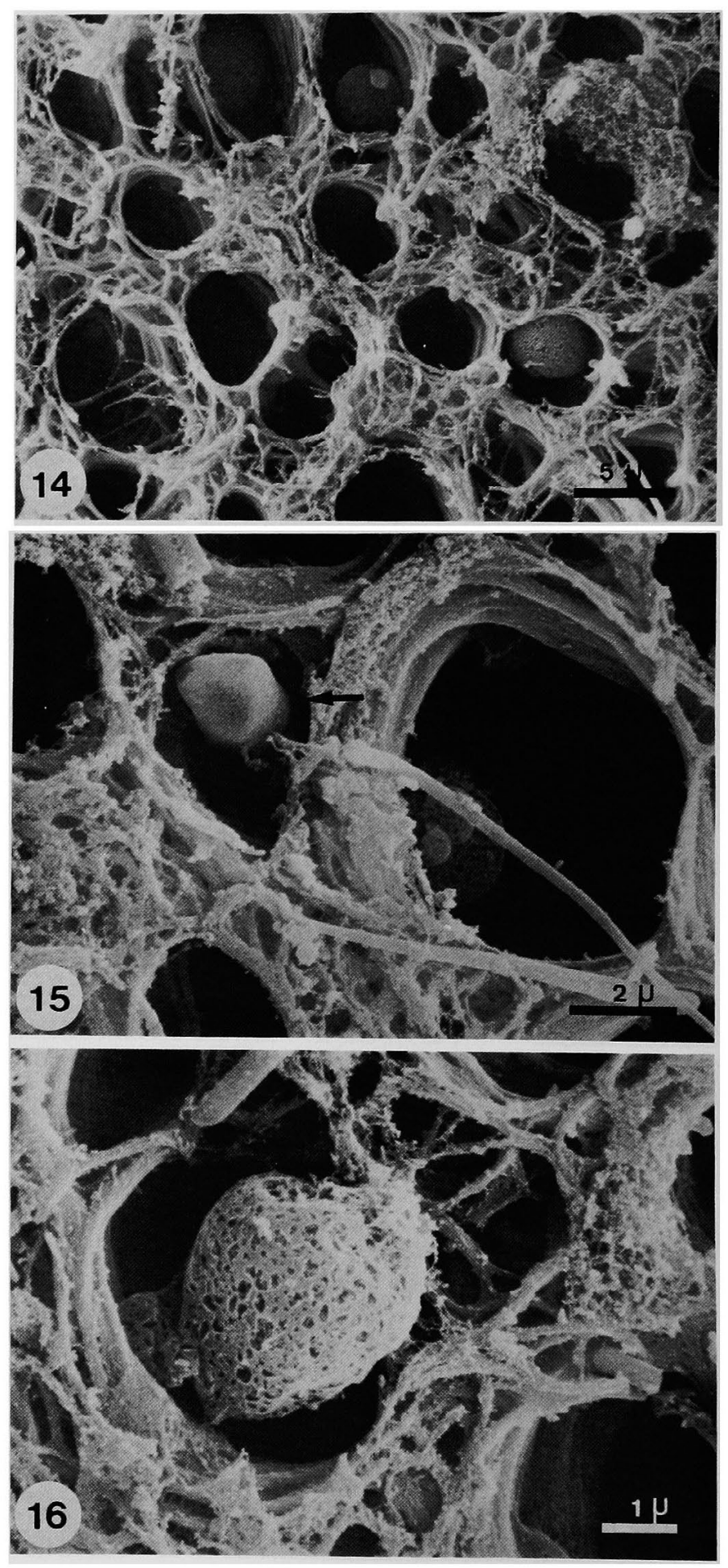
田頭 論 文 付 図 (5)
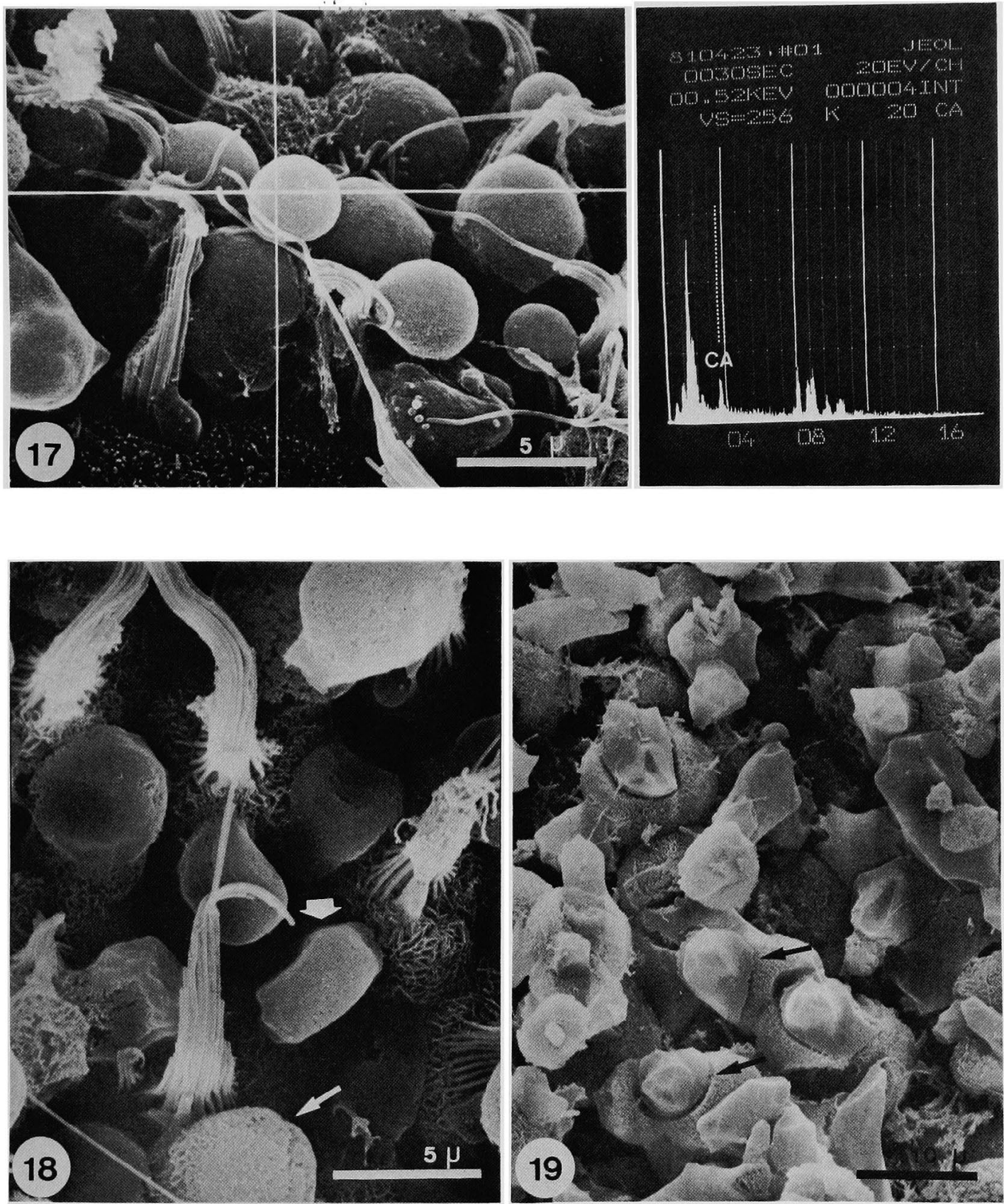
田頭論文付図 (6)
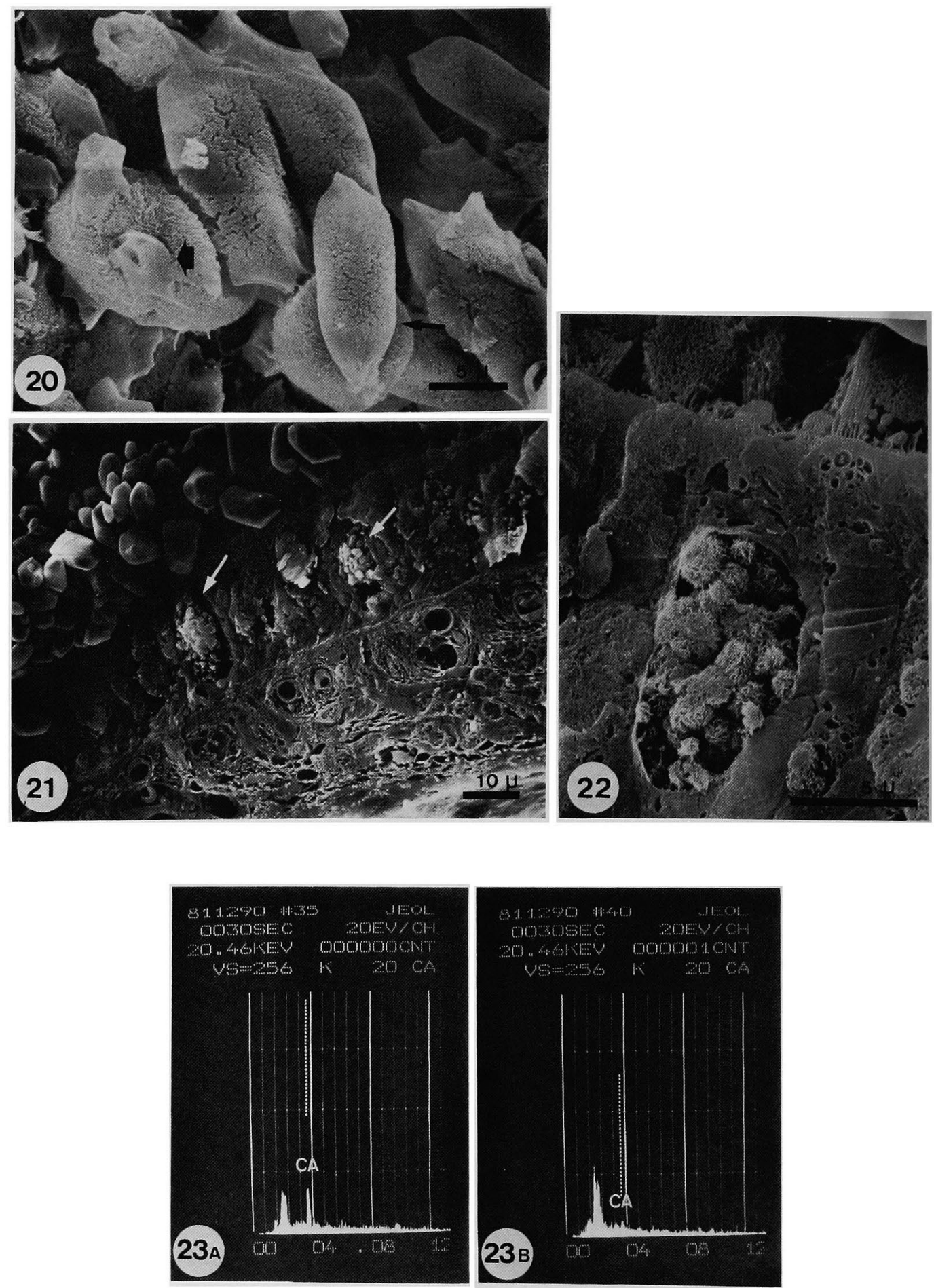
田頭論文付図 (7)
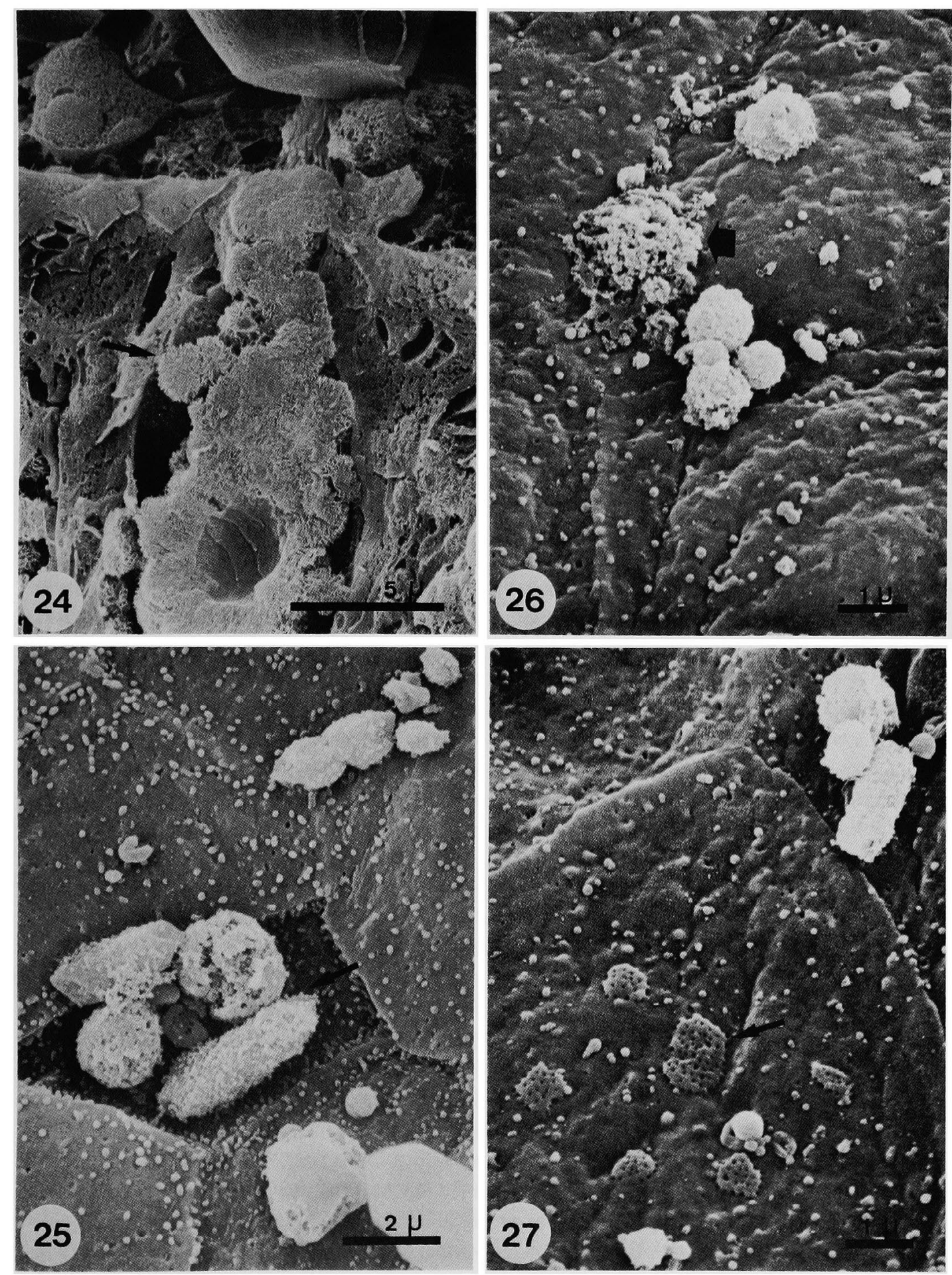
その型は円錐型，タル型，その他，種々の形態があり一 様性はなかった.さら飞耳石結晶が互い共有面で接し， 石垣状住組る合ったむのまであり，多くの点で表兽耳石 とは基なっていた．表層耳石の分布様式については倜体 差があるすのの，括括むね一致した傾向がみられた。

ii) $\mathrm{SM}$ 投与群

前述のごとく SM は，1週間徱に体重補正をしなが

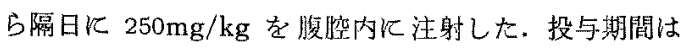
$2,4,6,8$ 週間上し，1，2，4，6，8 週後汇断頭し，你 処置群と同梯の操作で観察した。

SM 投与群はいずれの投与期間群で屯無処置群と山異 なった耳石形態と密度を示し，明らかにSM飞よる耳石 並びれ耳石層の変化と淓えられるすのを確認した、まず 耳石層の耳石の密度に閔しては, 全ての跭物で極端飞減 少し, その程度は投与量に比例していた。一力, 耳石の 形想については種々の变化を示した. 以下 SMによる耳 石の障害については，原田招上び著者らの報告 ${ }^{(3)}$ がすで にあるので䉍単化記す

a) SM 投与 2 週群: 投与終了後 2 週間目江はstriola

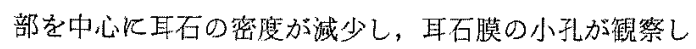
得る程になっていた. 耳石結晶は, 然処嘿群に扣いてと の大部分を占めていた 円柱型耳石が主体を成していた が，層状構造をもち，耳石体部の赤道部化黾裂の入った $10 \mu \mathrm{m}$ 以上の長径を有する大型耳石が增加していた。

b) SM 投与 4 週群: 耳石膜上の耳石の減少はさらK 高度となり，20〜30 $\mu \mathrm{m}$ もある大型ダンベル状耳石が多 数現われ, $3 \sim 5 \mu \mathrm{m}$ の整った絬晶型の耳石注極端に減 少していた。

c） SM 投与6週拉よび 8 週群：6週，8週投与群では ほぼ同椂の装化を示したので併せて述べることとする。 投与終了後 $1 \sim 2$ 週閶経過したものでは， striola 部を中

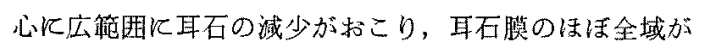
露出しているものも苛った. 耳石膜上深残存している耳 石は，その多くが SM 4 週間投与群でみられたような

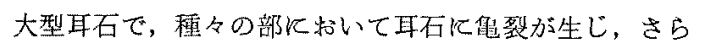
には崩填したものむあった。

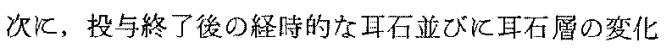
であるが、これは各投与咩とも似かよった推移を示した ので一括して述べる，投与終了後 4 週目には striola 部 の耳石層はまだかなり薄かったが，2週後のあの上比楁 すると小型耳石が增加していた，しかし，大型耳石は相 变らず多数みられ，正石体部の変化も 2 週後のものと大 差なかった。
6 週経過すると変形した大型耳石は極端飞減少し，代 って小型耳石の增加が目立ってきた.しかしながら，こ の小型耳石も無処置群でるられたような円柱型のものは 少なく，而端の三画構造功みられず，大きさ仕 $1 \sim 2$ $\mu \mathrm{m}$ と小型の不整結昆型であった。

8 週間経過する之総投与量比上る差舆恃多少あるもの の, 無処置群でみられたような $3 \sim 5 \mu \mathrm{m}$ の長径存有す 整った結晶形の耳石が大部分を占め, striola 部儿大型耳 石が少量みられるにすぎなかった。

以上の結果から，腹腔内投与された SM は耳石に強い 影響を及ぼし，その形態汇著しい变化を起こさせるこ とまたその数を減少されることが判った，一方，SM により障害を受けた耳石は，8週間後には正常に近い形

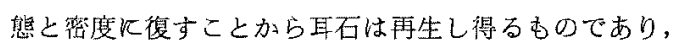
その期間は約 8 週と考えられた。

2) 耳石膜

a）耳石膜上面：無処置群動物のうち耳石の減少して いるものの耳石膜裴面の観察を行なった。これらの動物 では striola 部には正石が久提し，耳石膜の小孔が露出 していた。この耳石膜表面儿は直径 5 10 $\mu \mathrm{m}$ の球状物 啠が存在し，このうちあるものは耳石膜上飞遊離し，末 たあるものは耳石膜の小孔埋もれた状態たっった。こ の部で正常形態をした耳石, 球状物質, 耳石脱を，各々 $\mathrm{X}$ 線マイクロアナライザーによって Ca 含有量を測定し 比較至行なった．今回使用した分析器は元素の定星を行 ならことが不可能なため，湘定条件を一定上し，相対的

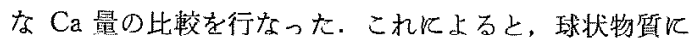
は正常形的をした耳石の約半量の $\mathrm{Ca}$ が検出され，一

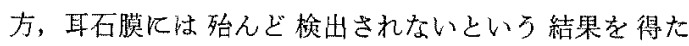
（図 11〜13). また，この球状物質の㳖面構造は粗で， スポンジ状，怪石状を呈していた，さらに極めて小型の 球状物質驾，結晶型となっている耳石表面に付着してい るものむ钼祭された。

b) 耳石膜下面（感覚上皮櫫面）：耳石膜下面を観祭 するためには雨面テープの小片を用いて耳石膜を感觉上 皮上り䟝離した。この面には耳石膜上面上同様沉，2 $5 \mu \mathrm{m}$ の径を有する小孔が無数炕あり，蜂栄状を呈して いた（図 14）。また，この面には值佳 $1.5 \sim 5 \mu \mathrm{m}$ の球

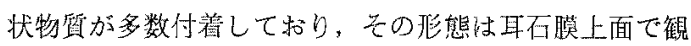
祭されたむの上極めて数似して拈り，裴面は怪石状ない しはスポンジ状であった。これらの球状物は耳石膜の小 孔内沉も存在し，この小孔内のもののち占少数のものは 直方体，あるいは耳石結晶に近いものまで種々の形態が 
観察された（図 15，16）。なかでむ耳石結晶に近い形態 をしたむのは，その表面構造が耳石層の最下層にみられ た耳石の構造と類似していることが判った。また，これ らの球状物質にもCaが含有されていた。

\section{3）感觉上皮表面}

燐酸䌅衝液の貲射により耳石膜の大部分は全層にわた って脱落したが，部分的には種々の原さで残存してい た.このため感覚上皮上で種々の耳石形態が観祭でき た. 感鸴上皮表面の露出している部では, 過去の報告に みられるように cilia 在する毛細胞と，この毛細胞を 取り囲んで配列する支持細胞とが観祭された，一方，こ れらの細胞の表面には顆粒状または球状物诈が多数認め られ，これらの物質にも $\mathrm{Ca}$ が含有されていた(図 17). この顕粒状物質の大きさは直径 $2 \sim 5 \mu \mathrm{m}$ で，その多く は球状であったが顆粒が瘾合して大きなものもあった。 また，その表面は細網状あるいはスポンジ様であった。 毛細胞を取り团んでいる支持細胞には，その表面が隆起 しているもの，岶るいは突出しているすのが多数観察さ れた. この突出した部の表面構造は, 細胞裴面より游離 した球状物質の表面と類似して括り，この突出部が細胞 より遊離し球状になるものと考兄られた（図 18）.今回 の観察で特に興味あることは，感覚上皮表面にある球状 物澌から耳石の形成が行なわれていることを示す所胃を 認め大ことである。すなわち，比較的大きな球状物質の 表面から明らかに耳石結晶とわかる構造物が突出してい た（図 19）。この結晶は大部分の正常耳石でみられる三 面構造を有し，また，その発生母体と思われる球状物質 と連絸性をもっていた．また一方では球状物澌全体が耳 石の結晶形へと変化しつつあると考えられるものもあっ た.これはその表面構造が未だ細網状を呈してはいるも のの, 全体的な形態は雨端が三面構造俘近い長棈円体を して括り，成熟耳石（あえてこういう名称を使うことと した）㳙つ前段階の未熟耳石と考方泉れた（図 20）。

以上の結果から感党上皮坟面江存在する球状物質が耳

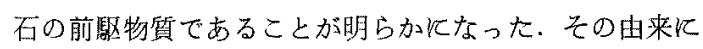
ついては前述のごとく, 支持細胞表面に㔖出物のあるこ と，また支持細胞表面任一致して Ca の集積があるとい 万原田の報告から，感觉上皮層の割断面の観察が必要々 考光た.

4) 感覚上皮層割断面

研究方法の項で述べたごとく、摘州した卵形整を DMSO 冷涑割断法（田中氏法）飞従って試料を作製し た.
過去の報告にみられるように，感覚上皮層の割断面に はフラスコ型の I 型細胞と, 長棈円型の II 型感覚細胞を 確認することができた。一方今回の観察では，これらの 感觉細胞と山別飞細胞内《多くの小顆粒を入れている新 たな所見が得られた（眓 21）。この小顆粒は直径 1２ $\mu \mathrm{m}$ の球状で，表面構造は細網状を呈し，感覚上皮表面 でみられ球状物孟と同物質であると考えられた（図 22).小顆粒物質について Ca 含有量の分析を行なった ところ, 結晶型耳石の約半量飞相当する $\mathrm{Ca}$ が㭘出され た. 他方, 顆粒を細胞内に含んでいない隣接した感覚細 胞炕ついてす同様の分析を行なってみたが，これには殆 えど Ca が含有されていないことが判った (図 23).さ らにこの顆粒状物質が細胞外，すなわら感覚上皮上に分 泌されつつある状態を観察することができ，アポクリン 分泌の様式と考光られた（図 24）。

以上の結果より, 平衡斑感営上皮層の支持細胞は $\mathrm{Ca}$ を合有する耳石の前駆物質を分班し，顆粒状となった耳 石前駆物質が結晶型耳石入上变化するものと考光られ た.

原田 ${ }^{16) 17)}$ は亦コの耳石膜を用いて，耳石生成部位が 平街斑感党上皮にあることを示唆する報告をしている が，今回の成績はこれを裹づける結果であった.

5）卵形缼暗細胞部

卵班琏平衡斑周囲にはオスミウム酸で濃染する暗細胞 が多数存在し，暗細胞領域と呼ぼれている。またこの 細胞飞注電解質の翰送飞関与する醉素の存在, あるいは イオン交換能のあることを示唆する報告がある。この㒹

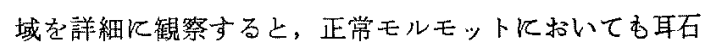
が暗細胞表面飞付着していることがわかった．これらの 耳不は耳石膜上でみられる耳石と形態的に同じものか ら，非常に異なったものとから棈成されていた．大部分 の耳石は，正常形態の耳石飞比べて耳石体部之三面構造 との境をなす稜線が不鮮明であり，三面構造もその形が 崩れていた。また，これらの耳石はその表面の状㲘が特 徵的で，怪石を思わせるような小孔が多数あいていた。 耳石全体の形態として前述のごとく，正常形態飞近いも の加ら，やや形の崩れたもの，さらには取石の外殼部が 溶けて潰れたようなあのまで種々の形態をしていた（图 $25,26)$.これらの耳石の $\mathrm{Ca}$ 含有の程度を分析したと ころ, 崩壊の強い屯の程その含有量は少なく, 潰れたよ ろなむのでは殆儿ど Ca を険出し得なかった．また暗細 胞表面汭は，これらの崩壊耳石湿ざって小孔をむった 網状構造の新たな物犋が付着していることがわかった。 
この物質は崩壊の激しい耳石とその一部が連続している あのや，遊離して単独存在しているものがあった（四 27).この物質には Ca が検出されず，耳石結晶から Ca が完全に吸収された後の organic matrix が残ったむの と考元た。これらの变形耳石, 崩塤耳石あるい性網状構 造の物質は，平衡斑耳石膜上でみられることはなく，耳 石膜上の耳石は暗細胞上汇落下するとこの裴面に财着さ れ，脱カルシウムされると考光た。また残った organic matrix 李いずれは吸収され，暗細胞上より消失するむ のと思われた，一方，SM を投与された動物では，暗細 胞上飞付着している耳石すなわ占平衡斑上から落ちた耳 石が正常動物のそれより多い事が判った．この事てつい ては原田ら 関しては明らかではないが，SM は耳石の耳石膜への結 合を弱める作用のあることが示晙された。

\section{IV 考察}

最近の透過型電顕 (TEM), 走查型電顕 (SEM) 飞よ

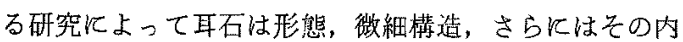
部構造までが明らか汇されてきた。登椎動物の平衡斑は 感覚上皮層と耳石膜より成り，耳石膜はさらに耳石層々 ゼラチン層より成るという説引181819)，あるいは電子密度 の相異から Marginal Zone と Medial Zone ${ }^{20)}$ ，また cupular zone 1，2 といった層より成っているとの報 告があり ${ }^{212}$, 耳石は耳石膜を棈成する一部としてあつか われている。しかしながら，今回の矿究加らは耳石膜と 耳石層とを2層に分けるべきて，耳石膜柱多孔性の膜様 物質より成ると考えた方がよい様に思われた，事实，固 定された耳石膜注明らか江多孔性構造を屯ち，この小孔 の中江耳石の前駆物質あるい泩未熟耳石を入れて扰り， これらの通過を許している。

耳石の形賏関して報告は数多くなされて和り，上卜 をはじめとして唃乳動物で㤬基本的にほほ同様の形をし ている. SEM による観察では耳石結晶はその多くが両 端酒三面構造を有する円柱体で，その他炕ダンベル型， 十字型，卵形，小結晶が瘾合したようなものなど種々の 形のものが観察できる。しかし，一般に成熟した動物で 法最初に述べた円柱体で車端に二而構造をるつ型が主体

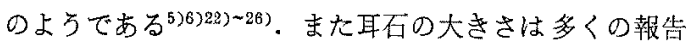

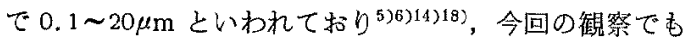
これと一致していたが，成熟モルモットでは $3 \sim 4 \mu \mathrm{m}$ の長径をむつ円柱型耳石加多加った。平衡斑全体の耳石 の形態とその分布様式飞ついては Ross ${ }^{(3)} や \mathrm{Lim}^{5)}$ が
すでと詳細な報告をしている。これらの報告炕ると， 一般に striola 部之弯入部付近では他の部に比べて耳石 が小型であり，耳石層の㳭部では大型耳石が目立つとし

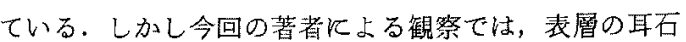
に関して striola 部では他の部比へで小型であるもの の，個体によっては大型のものもみられ， $\operatorname{Lim} の$ 報告と は必ずしも一致しない結果が得られた。一方，耳石層深 部の耳石については確かに大型のものが多く認められた がここれらの耳石の形態は表層のものと比べると不揃い で変形したものが多く，その表面も粗であった。これら

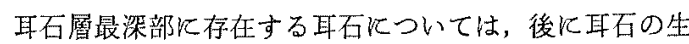
成に関する部で再び詳細に述べる。

耳石結鼠飞ついて Carlström ${ }^{2}$ は X線回析有いて， これが炭酸カルシウムの結晶であることを示し，その後 の追陚にても同様の結果が報告されている3225) また， Ross $^{6)}$ 湠酸カルシウム以外汇微量のマンガン, 硫黄, 燐などを検出している。

耳石の生成については過去には幾つかの説があるもの の明碓な根拠はないよろである、Vilstrup ${ }^{27)}$ はサメの耳 石について endogenousな耳石と exogenousなものが あり，前者は迷路あるいは内リンパ翼で耳石が形成さ れ，後者では砂粒を体内に取り込むというものである。

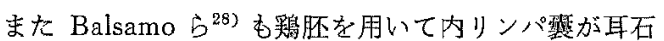
生成の部であることを示唆する報告をしている。一方， 最近は TEM による钼祭で耳石の内部構造が明らかル されつつ岕る、これによると，耳石の中心部と辺緑部で は電子密庡が異なって抢り年20321)，これを central core あるいは耳石の nucleus と呼び，么コ多啸体 ${ }^{\text {(5) }}$ ，糖蛋白 29)加ら成っているとされている。そして，耳石はこの 中心核に Ca 肪沈着すること炕って形成されると考光 られていた。 以上の事実が明らかれされ， $\operatorname{Lim}^{5)}, \operatorname{Ross}^{6)}$ 等はこの中心物質こそが耳石形成の際の基本物澌と奨 え，これを organic matrix と呼えでいる。一方, Salamat ${ }^{29)}$ は胎児ラットの耳石を TEM で観察し，こ の中心核となっているものはををも方初期の耳石の原型 でありすてて炭酸カルシウムとしての結晶形妾成し， この周困にさらにカルシウムの视着が生じて成熟型耳不 飞成長すると報告している．以上の上う飞耳石の中心椟 をな物質が耳石の形成に関与していることが明らかに なってはいるものの，この物質の起源については未知の ままである，最近，原田は平衡斑感覚上皮上飞球状物犋 の存在するこ上を確認し，この物質が耳石の原型となる 毛のではないかとの報告をしている1617) 今回の観察に 
拈いても，卵形变斑耳石膜の表面，耳石膜の小孔内，灻 た感覚上皮表面に同じ形態の物質を認めることができ た. さらにこの球状物睤の一部加ら耳石結晶が形成され つつある状態，きた球状物澌の一部のみでなく全体が耳 石結晶へと变化しつつある所見を得た䚿であり，今まで いわれているような，核を中心としてこれに炭酸力ルシ ウムが沈者することによって耳石結晶が形成されるとい ら説とは異なった結果を得た。これらの球状物質は結晶 型耳石の約半量の Ca 考会有し, 結晶型耳石入变化しつ つあるむのではさらに多量の Ca を含有しているという

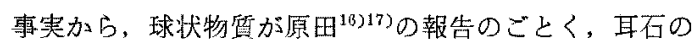
原型であることは閐進いないと考えた.今回著者はこの 球状物質を耳石前眼物質と呼ぶこととするが，この物留 の起源次いてむ, 原田は平衡斑感觉上皮表面の Ca 元 素分析の結果上り，支持細胞からの分泌の可能性を示唆 している(16)(7). 従って, 今国の観祭で明らかになったと ころの感覚上皮層支持細胞内の顆粒の存在は非常に與味 深いものである。さらにこれらの小顆粒は成然型耳石 の䄪半䁷のCa t念有して战り，顆粒状物留が細胞外一 放出されつつある状態もとらえることができた。このよ 弓な事実加ら，平衡斑感㽞上皮表面，あるいは耳石膜小 孔括よびその表面でみられた球状の物質は耳石前瞜物 質であり，この前歌物質は支持細胞で造られると結諭し た.この耳石前駆物質の耳石結晶への変化についてはま だ末知な部むあるが, 過去の報告にあるように, 中心核 の周用炕ルシウムイオンが沈着し, 結晶型人上育つと するのはやや不合理な感がする。すなわち，耳石が平鲢 斑上Kのみ整然と存在している事実の説明に難があると 思わ机るし，耳石結晶の形態，大きさにしても一様性の 傾向があることを説明しにくい，反対に今回の钼察で明 らか江された事実は，これらの点についての説明が納得 のいくものと考光られる，すなるb，耳石前駆物㑭は平 衡斑感觉上皮層より分透されるのであるから, 耳石は平 斑斑上にのみ整然乞存在するのであり，大ささの一様性

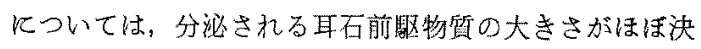
まっているからである。大型の耳石については，これら の耳石前駆物啠が䈍合した状態で結晶化したすのと考え られ，1ケの前駆物買が結昆化したり，1ケの前駆物質 加複数の耳石結晶加生した際には比較的小型の耳石之 なることが考えられる。

耳中表性物犋による平衡斑の障害については退去にか なりの報告がなされてい。. Berg光はストレプトマイ シン (SM) 投与飞より感觉上皮の障害と, 耳石膜（こ
の場合はゼラチン層と耳石層を含んだものをさしてい る）の久唄が生じると述へ， Spoendlin ${ }^{8)}$ はとの障害が I 型感細胞に強いとしている. 一方, Lindeman ${ }^{93}$ は $\mathrm{SM}, \mathrm{KM}$ (カナマイシン) の毒性について，前庭放よび コルチ器の障㕩の受㩯性の差異党報告しているが, 耳石 膜飞は变化がないと遮へている. Johnsson ${ }^{30312}$, 綿貫 ${ }^{12)}$,

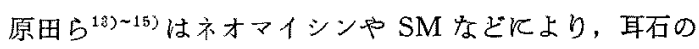
減小と異掌耳石の出現すること老報告しているが，耳石 各㑑の㝝化について螌れているすのは少ない，綿貝 ${ }^{12}$ は SM 飞よる耳石の隇少原团について，(1) 耳石の Ca 代 謝の障害，（2）平衡斑感觉上皮の感觉毛が消失すること によって耳石膜の支持が失和れ，ひいては耳石の降害を 起す，という二つの仮説を立てている，著者らの研究結

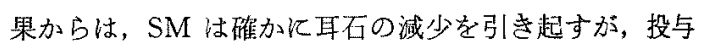

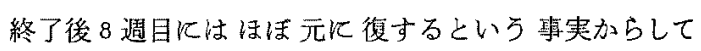
${ }^{15) 32)}$, SM は耳面の Ca 代媩飞何ら汃の異管を引き起す

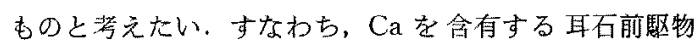

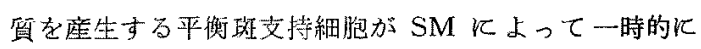

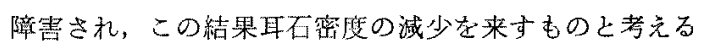
こしができる。

一方, 正常動物でも耳石の減少, 欠損は有り得る。上 卜の場合，加路に上万耳石の堿少と耳石結晶の崩壤吕報

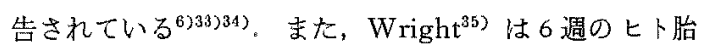
児で耳石の全欠損例を報告している，さらに拻酸脱水素 醉菜抑制剂の投与年，またマンガンや互鉛の久之によっ て耳石欠椇が起こることが動物実験で確かめられてお り，これら2つの元素が耳石形成に際して乘要なもので あると舟言われている

Johnsson ${ }^{10)}$ は無処固のモルモットにも約20\%に耳石 の減少，あるいは欠提したものがあり，耳中埥性物質に よる耳石減少について見西しの必要性を報告している.

著者ら屯約 $40 \%$ 率で耳石の減少のあることを報告して いるが41) SM 投与群で估全例に耳石の減少や欠損上形 热の異常を示して和り，SM が耳石の障㕩を引き起すこ とは閐量いのない事実上考兑る。

耳石の成分であるCaが代謝していることは過去の報

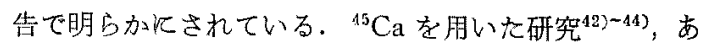
るいはラベルしたテトラサイクリン28)で耳石のCa は その表面で常に吸収と阴沈着があるものとされ， $\operatorname{Lim}^{6}$ はこの際，耳石の結晶形热に变化は生しないと述べてい る、しかしながら耳石償上に存在する全ての耳石表面で Ca の吸収と再沈着とがパランスよく行わ机, 耳石結晶 構造を損なわないとするの沙常に特異的な機構の感が 
するし，耳石の新生という事类がどうなるのかが問題と なろう。一方, Preston ${ }^{44}$, Mechigian ${ }^{45)}$ は耳中等性物 質の投与により耳石器でのCa の取り込みが隇少すると 述べているが，これは SM K上る耳石の減少あるい甘 欠損を支持する絬果と㹲えられる。ざに，Ca の取り 込みの倵少という事彗は，本诃究で明らかにされたとこ

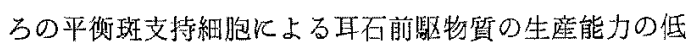
下につながるむのと䓅えられる。

いずれにしても耳石の Ca 代代謝して招り，この結果 耳石が新生と崩流をくり返しているのは事实である。こ のうち新生については前述のごとく平衡斑感覚上皮の支 持細胞によって耳石前駆物貿が生産されている訳である が，耳石の吰収飞関して明確な意見はなかった． $\mathrm{Lim}^{6)}$ 46)は，耳石孛脱灰することによりゼラチン状の物澌が 残ることをSEMで確認し，この物質が耳石の organic matrix K相当するものであるとしているままた彼は TEM Kよる観祭でも前庭暗細胞上に干しブドウ様の物

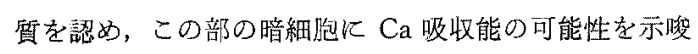
した. 一方, 前庭暗細胞にはイオン交換能の存在も報告 さ机ている. Nakai ${ }^{47)}$ は Na-K D愉送に関する醉素て ある AT Pase の存在を示し, Smith ${ }^{45)}, K_{\text {Kimura }}{ }^{49)}$ は

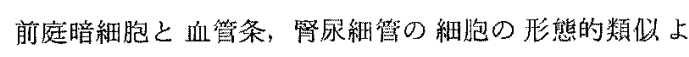
り, 前庭暗細胞にイオン交換能の存在を推祭している. これらの報告から前庭暗細胞に Ca イオンの吸収能の存 在が充分にうかがえるのであるが，耳不の Ca が吸収さ れることを明らが示し報告は闑い.今回の一邀の観察

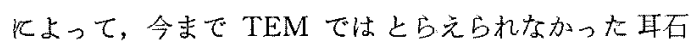
の吸収邀程を種々の相で確認し得た。すなかち, 前庭暗 細胞の表面には正常班態の耳石上上もに，その表面が怪 石状となった耳石, さら外款を保つべきカルシウムが 吸収されて㴹れたよらな耳石，てして最後の段階として

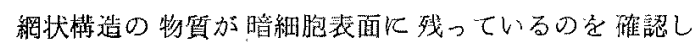
た. この網状棈造物犋について Ca 元素分析を行なって みたとこる Ca 合有されて枯らず，この物質こそが， 耳石のCa 成分が全て吸収された後に遗された organic matrix と侾えられた. この organic matrix むいずれ は吸収されて，陗細胞表面から泚えてゆくようであり， 前庭暗細胞には耳石の脱力ルシウム作用と, pinocytotic な機能が存在することを今回の矿究で確認し得た。

\section{V 結 語}

热処犆执よびストレプトマイシン投与のモルモットを

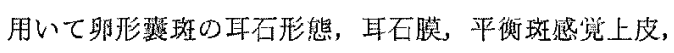

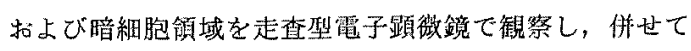
X線マイクロアナライザーによるカルシウム元素分析を 行い次のような結論を得た。

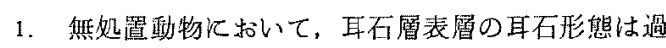
去の報皆とほぼ一致していたが，耳石層深層に存在する 耳石は大型であるのみならず，その形態は表尿の耳石と 比べて極めて異なっていた。これら深層にある耳石は結 鼠型の未熟な耳石と考えられた。

2. 無処置㗢物の約 $40 \%$ に石の減少しているものが あった。この減少は左右の卵形翼扣よび球形翼でみられ

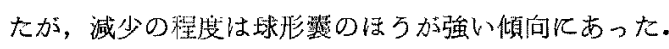

3. ストレプトマイシン（SM）の投与を行うと，全 例の陲物に招いて耳石層の密度が減少していた，残存し ている耳石は大型で噟状構造を有する結鼠形瞋のものが 增加していた。

4. SM による耳石の減少と形態の㓋常岵投与終了後 䄪 8 週間で回復することが判った。

5.SM投与により耳石と耳石膜の接着性が瑟くなり， この絬果, 多くの耳石が耳石層より平衡斑周目に脱落し ていることが明らかとなった。

6.耳石膜表面，耳石膜の小孔内，交た耳石膜感觉上 皮面に球状物質の存在することが確認できた。これらの 物質には結晶形耳石の約半量に相当するカルシウムが合

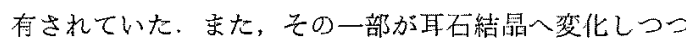
あるるのを発見した。

7. 平衡斑感喾上皮表面でも球状物翼が存在して特 り，この物質の一部加ら耳石結晶が形成されつつある状 態, また球状物質全体が耳石結晶人と变化しつつあるも の走発見した、このような事実から，球状物質は正石の 前駆物翼と考えた.

8. 平衡斑感覚上皮盗を棈成する支持細胞荠面炕 Ca

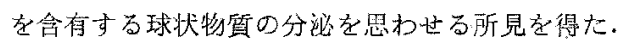

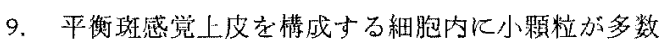
含まれているもののあることを発胃した。小顆粒には力 ルシウムが含有されて扣り，この物胬が分泌されて耳不 前駆物買となりささらに耳石結昆となるものとの確証を 得た。

10. 聑衡斑周明の暗細胞領域には耳石が付着してい るが、この部にある耳石は種々の崩堛過程にあった。こ のことから耳吕は暗紐胞素面で脱力ルシウムされ，最後 飞organic matrix のみとなるが，これも最終的には吸 収されるむのと結諭した。 


\section{参考 文 献}

1) 26) より引用

2) Carlström D, Engström $H$ and Hjorth S: Electron microscopic and $\mathrm{X}$-ray diffraction of statoconia. Laryngoscope 63: 1052-1057, 1953.

8) Carlström D and Engström H: The ultrastructure of statoconia. Acta Otolaryngol (Stockh) 45: 14-18, 1955.

4) Sanchez-fernández JM, Marco J, Rivera-Pomar JM and Delgado RM: Electron diffraction studies on otolith organization in the macula utricli of the guinea pig. Acta Otolaryngol (Stockh) 73: $267-269,1972$.

5) Lim DJ: Formation and fate of the otoconia. Ann Otol 82: 23-35, 1973.

6) Ross MD, Johnsson LG, Peacor D and Allard LF: Observations on normal and degenerating human otoconia. Ann Otol 85: 310-326, 1976.

7) Berg K: The toxic effect of Streptomycin on the vestibular and cochlear apparatus. Acta Otolaryng (Stockh) Supple: 97, 1951.

8) Spoendlin HH: Zur ototoxizitat des Streptomyzins. Pract Otolaryng (Basel) 28: 35, 1966.

9) Lindeman HH: Regional differances in sensitivity of the vestibular sensory epithelia to ototoxic antibiotics. Acta Otolaryngol (Stockh) 67: 177$189,1969$.

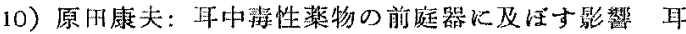
㐿 23: 604-608, 1977.

11) Harada Y: Morphological changes in the vestibular sensory organs after streptomycin intoxication. Scanning Electron Microscope, II . 1077$1082,1978$.

12）鼣貫幸三，河本和友，片桐主一: 前庭耳石器官のス

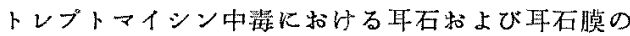
変化 日开睤 75：539-545，1972.

13）原国康大，杉本敌朗，田頭宣治：ストレブトマイン

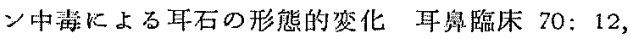
1943-1949, 1977.

14) Harada $Y$ and Sugimoto $Y$ : Metabolic disorder of otoconia after streptomycin intoxication. Acta Otolaryngol (Stockh) 84: 65-71, 1977.

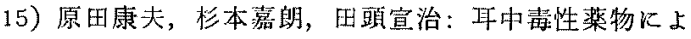

る耳石代暗障害の研究 内耳生化学 7:60-62, 1976.

16）原田康夫：耳石の生成部位について。 Equilibrium Research 37: 217-220, 1976.

17) Harada Y: Formation area of the statoconia. Scanning Electron Microscopy $\mathbb{I I}, 963-966,1979$.

18) Dohlman GF: The attachment of the cupulae, otolith and tectorial membranes to the sensory cell areas. Acta Otolaryng 71: 89-105, 1971.

19) Lim DJ: Ultrastructure of the otolithic membrane and the cupula: Scanning electron microscopic observation. Adv Oto-Rhino-Laryng (Kargen) (In press)

20) Marco J, Sánchez-Fernández JM and RiveraPomar JM: Ultrastructure of the otoliths and otolithic membrane of the macula utriculi in the guinea pig. Acta Otolaryng 71-1-8, 1971.

21) Igarashi $M$ and Kanda $T$ : Fine structure of the otolithic membrane in the squirrel monkey. Acta Otolaryng (Stockh) 68: 43-52, 1969.

22) Lindeman $\mathrm{HH}$ : Studies on the morphology of the sensory regions of the vestibular apparatous. Adv Anat Embry Cell Biol 42: 1-113, 1969.

23) Lim DJ and Lane WC: Vestibular sensory epithelia. Arch Otolaryng 90: 283 292, 1969.

24) Lim DJ: Three dimensional observation of the inner ear with the scanning electron microscope. Acta Otolaryng (Stockh) Supple 255: 38, 1969.

25) Kellerhalls B, Marti E and Villiger W: Surface view of the guinea pig otolithic membrane. Pract Oto-Rhino-Laryng 32: 65-73, 1970.

26) Ross $\mathrm{MD}$ and Peacor $\mathrm{D}$ : The nature and crystl growth of otoconia in the rat. Ann Otol Rhinol Laryngol 84: 22-37, 1975.

27) Vilstrup $T$ : On the formation of the otoliths. Ann Otol 60: 974-981, 1951.

28) Balsamo G, DeVincentiis $M$ and Marmo F: The effect of tetracycline on the processes of calcification of the otoliths in the developing chick embryo. J Embryol Exp Morph 22: 327$332,1969$.

29) Salamat MS, Ross $\mathrm{MD}$ and Peacor DR: Otoconial formation in the featal rat. Ann Otol 89: $229-238 \cdot 1980$. 
30) Johnsson LG and Hawkins JE Jr: Strial atrophy in clinical and experimental deafness. Laryngoscope 82: 1105-1125, 1972.

31) Jhonsson LG et al: Streptmycin-induced defect of the otoconial membrane. Acta Otolaryng 89: 401-406, 1971 .

32）田頭宣治，原四廝夫：ストレブトマイシン中清によ る耳石の形熊的変化再生過整に特ける形態内耳 生化学 10: 50-52, 1979.

33) Johnsson LG: Degenerative changes and anomalies of the vestibular system in man. Laryngoscope 81: 1682-1694, 1971.

34) Johnsson LG and Hawkins JE Jr: Sensory and neural degeneration with aging, as seen in microdissection of human inner ear. Ann Otol Rhinol Laryngol 81: 179-193, 1972.

35) Wright CG, Hubburt DG and Graham JW: Absence of otoconia in human infant. Ann Otol 88: $779-783,1979$.

36) DeVincentiis $M$ and Marmo F: Inhibition of the morphogenesis of the otoliths in the chick embryo in the presence of carbonic anhydrase inhibitors. Experimentia 24: 818-820, 1968.

37) Erway LC, Hurley LS and Fraser AS: Congenial ataxia and otolith defects due to manganese deficiency in mice. J Nutr 100, 643-654, 1970.

38) Erway LG, Fraser AS and Hurley LS: Prevention of congenital otolith defect in pallid mutant mice by manganese supplementation. Genetics 67: 97-108, 1971 .

39) Lim DJ and Erway LC: Influence of manganese on genetically defective otolith. Ann Otol 83: $565-581,1974$.

40) Johnsson LG, Wright CG, Preston RE and Henry PJ: Defects of the otoconial membranes in normal guinea pigs. Acta Otolaryngol. 89: 93$104,1980$.

41) Harada $Y$ and Tagashira N: Metabolism of otoconia. Biomedical Research 2, Supple. 415-420, 1981.

42) Belanger LF: Observations on the development, structure and composition of the Cochlea of the rat. Ann Otol. 65: 1060-1073, 1956.

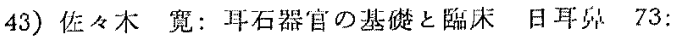
1975-1983, 1970 .

44) Preston RE, Johnsson LG, Hill JH and Schacht $\mathrm{J}$ : Incorporation of radioactive calcium into otolithic membranes and middle ear ossicles of the gerbil. Acta Otolaryngol (Stockh) 80: $269-275,1975$.

45) Mechigian I, Preston RE, Johnsson LG and Schacht J: Incorporation of radioactive calcium into otolithic membranes of the guinea pig after aminoglycoside treatment. Acta Otolaryng (Stockh) 88: 56-60, 1979.

46) Lim DJ: Vestibular sensory organs. Arch Otolaryng 94: 69-76, 1971

47) Nakai $Y$ and Hilding D: Vestibular endolymphproducing epithelium. Acta Otolaryng 66: 120$128,1968$.

48) Smith CA: Microscopic structure of the utricle. Ann Otol. 65: 450-469, 1956.

49) Kimura RS: Distribution, structure and function of dark cells in the vestibular labyrinth. Ann Otol. 78: 542-561, 1969

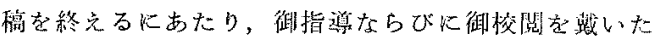
恩師原田康尖教授に哚く感謝致し未す

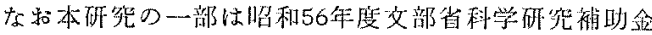

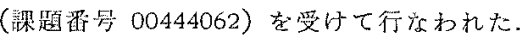

本詇文の要旨は第26国日本内经化学研觉会，第81回 日本叿非四喉科学会総会, International Symposium on SEM in Cell Biology and Medicine た拉いて無琵し た

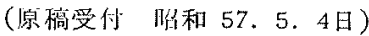

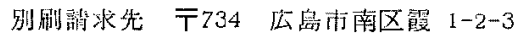

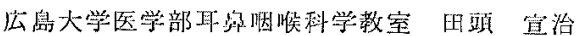


付図説明

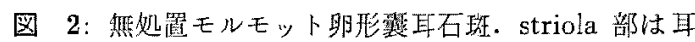
石層がやや溥く波状を星している $(\rightarrow)$.

図 3: 外側辺縁部の古石は長经が $1 \sim 3 \mu \mathrm{m}$ の小型の 卵型のもので占められている.

图 4: striola 部之外側辺緑部之の中間部。定型的な結 鼠で，雨端儿3面構造を有する耳石が目立つ。ま た $1 \mu \mathrm{m}$ 以下の極小耳石手みらる。

図 5: 耳石算深部にみられる耳石は三面粠造を有する ものの，表智耳石のものとは異なっている。また， 耳不体部屯円柱状でないものが多い，耳石結晶が 円錐状のものもある $(\rightarrow)$. 耳石体部球状物質肪 付着しているものもある $(\mapsto)$.

図 6: 耳石曆深部存在する耳石の表面は細網状を星

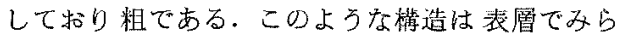
れる耳石結鼠の前段階であり未雉耳石である。

図 7: striola 部での表層耳石. 定型的な耳石結罪がそ の多く占めているが，層状棈造をもつダンバル 型の大型耳石が目立つ。

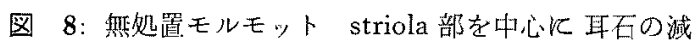
少がみられる。このため耳石膜表面の絸状棈造が 琵出している.

図 9: 図8の striola 部の拡大. 耳石膜の小孔之層状 擈造を有する大型のダンベル型の耳石が多くみら 机る。

图 10：然观䈯モルモットの striola 内側部. 足型的な 耳石が大部分を占めるが，不规則な北をした大型 耳石が湝ざっている $(\rightarrow)$.

図 11：耳石槕上にある結晶型耳石の Ca 元舁分析（分 析部位は縦荟の白線の艾点)，右のグラフは高いピ ークが Ca走す.

図 12: 耳石膜のみを分析すると少量の $\mathrm{Ca}$ (結晶型耳石 の約 $1 / 8$ ）が检出された，これ虫耳石笑の下層に ある耳石前駆物犋の Caを检出している可能性加 ある。

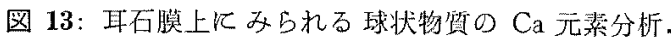
この物啠烧有されている Ca 半量である。

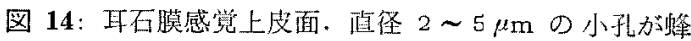

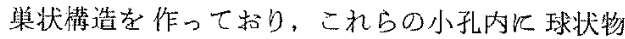
新がみられる。

図 15: 小孔内には耳石結晶に近い形態をしたものもあ

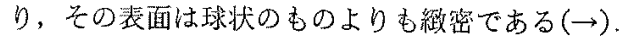

図 16: 小孔内にある球状物澌の拡大. 表面はスポンシ 状量している。

図 17：平衡斑感筧上皮表面飞みられた球状物犋. Ca 元 絜分析を行うと少量ではするが检出されている。

図 18：cilia 有する感賞細胞の周囲火架出物が多数み られる。あるものは球状(一)，または結晶化しつ つあるもの娄みられる（中)。

図 19: 卵形嫼斑感党上皮上飞みられた多くの顆粓状物 買、その一部より耳石結晶が生まれている $(\rightarrow)$. 結晶形は耳石畨表面の毛のとは買なっている。

図 20：耳石前駆物質加耳石結晶へ上变化しつつおるも の( $\rightarrow)$ ，また小形の耳石が耳百前臤物質より生し ている（一)、耳石の表面は細網状で粗である。

図 21: 卵形胎斑感賞上皮層の 割断面. 細胞内化小顆稙 を合もものがある (

図 22: 小顆粒を佥む細胞の拡大．顆粒の直径は，1 $2 \mu \mathrm{m}$ で細胞内に充落している.

図 23:（A）図22 で示した顆粒の $\mathrm{Ca}$ 元素分析. これは 結晶形耳石に扣いて㭲出さ机䁷の約半量に相当 する・

（B）組胞内に顆精のないI 型感党細胞を(A) と 同じ多件下K $\mathrm{Ca}$ 分析した娄の. Ca 将全く検出さ れない。

図 24：卵形琵斑感觉上皮割断面. 細胞内顆粒と $(\rightarrow)$, その一部が細胞外入分泌されている

図 25，26: 前庭暗細胞表面儿付着している耳石.この 部の耳石は正常形態汇近いものから，表面が軽石 状乞なったもの ( たようなもの（）市である。これらは耳石の Ca 叹収の種々の段階を示していると考光られる。

図 27：前庭暗細胞裴面にみられる網状構造をした物啠 $(\rightarrow)$ ，この物質心崩壊の激しい耳石の傍にもみら れることから耶石のCa 成分が消失した後に残っ たorganic matrix と考光られる。 